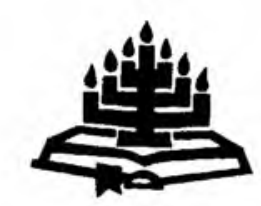

\title{
Algemeen of bijzonder Christelijke ethiek in een moderne cultuur
}

\author{
W.H. Velema (Emeritus-hoogleraar) \\ Departement Ethiek \& Diaconiologie \\ Theologische Universiteit \\ APELDOORN \\ Nederland
}

\begin{abstract}
General or particular. Christian ethics in modern society

In this article the author investigates the relation between fath/revelation on the one hand and ethics on the other; the relation between the "particular" and the "general". It is argued that Rendtorff and Pannenberg are basically in agreement that ethics does not depend on Christian faith and divine revelation, although there is a connection between the two. On the other hand, the author of this article (in agreement with Douma) relates faith/revelation and ethics very closely: ethics is directed by a life and world view - a stance illustrated by a discussion on abortion and euthanasia. The issue of consensus on moral issues between Christians and non-Christians should be resolved from the perspective of the general goodness of God and his law, given to all men.
\end{abstract}

\section{Publicaties over het probleem}

\subsection{Wolfhart Pannenberg}

Genoemde onderwerp wordt door velen besproken. Het is van veel kanten te benaderen. ${ }^{1}$

De Münchener emeritus-hoogleraar in de systematische theologie, Wolfhart Pannenberg, heeft een studie gewijd aan de grondslagen van de ethiek. Hij is bij de Griekse wijsgerige ethiek begonnen. Van voor Plato tot na Aristoteles heeft hij het spoor getekend. Vervolgens komen Augustinus en Thomas aan de beurt.

1 Het gaat mij in deze bijdrage aan de feestbundel voor onze gewaardeerde collega, Paul de Bruyn, om commentaar op cen recente discussie. 
Pannenberg geeft ruime aandacht aan Engelse wijsgerige ethici en aan de radicale verschuiving die Kant heeft teweeggebracht. Zo komt hij bij de situatie van de twintigste eeuw.

Kants autonomie-these fungeert als een breekijzer tussen ethiek en religie. Het zou onjuist zijn te denken, dat Kant de ethiek beschrijft zonder aandacht voor de religie en voor het geloof in God. Kant heeft wel ruimte voor die relatie. Echter niet zodanig, dat de ethiek haar basis vindt in de religie. Ethiek heeft wel wat gemeen met religie, maar ethiek wordt niet bepaald door religie. Ethiek is een zelfstandige wetenschap, zoals de mens een autonoom handelend subject is. De kern van de discussie betrof de vraag of we religie nodig hebben voor moraal, dan wel of religie ook zonder moraal kan. Sommige auteurs ontkennen de noodzaak van religie als basis voor de moraal.

In de lijn van Kant zijn er verdedigers van een autonome ethiek, die plaats hebben voor een inbreng van het christelijk geloof. Deze inbreng is echter bijkomstig. Zij laat de autonomie van de mens als handelend subject onverlet. De autonomie staat voorop. Douma heeft de autonomiegedachte vergeleken met een paraplu, waaronder elke ethiek in welke modificatie ook, zich moet stellen (Douma, 1991:57-60).

\subsection{Trutz Rendtorff}

Zo komen we bij het thema: christelijke ethiek in een moderne cultuur. Ik herinner aan twee discussieronden. De ene is in Duitsland gevoerd tussen Wolfhart Pannenberg en Trutz Rendtorff. De eerste heeft na zijn emeritering geschreven over de grondslagen van de ethiek. Na het hierboven vermelde historische overzicht heeft hij zijn eigen positie uiteengezet. Hij doet dat in een discussie met zijn collega in de sociale ethiek, Rendtorff. Het is een charmante discussie. Pannenberg heeft dit boek opgedragen aan Rendtorff ter gelegenheid van diens 65 ste verjaardag. Hij beschouwt zijn discussie met Rendtorff als een (noodzakelijke) aanvulling op diens werk. Hij noemt het werk van zijn collega wegwijzend (Pannenberg, 1996:6). Dit wijst erop dat de overeenkomst tussen de beide collega's groter is dan het verschil. Uit mijn hieronder volgend commentaar op beider positie zal blijken, dat hun verschil mij nog kleiner voorkomt dan Pannenberg denkt.

\subsection{Discussie in Trouw}

Over het thema is in Nederland het een en ander gepubliceerd. In het dagblad Trouw hebben scribenten van zeer verschillende herkomst hun visie gegeven op het vraagstuk van moraal en religie in een geseculariseerde samenleving. De artikelen uit Trouw zijn gebundeld (Steenhuis, 1996). 


\subsection{Jochem Douma}

Douma heeft aan deze discussie het artikel gewijd dat hij in de afscheidsbundel voor Manenschijn heeft geschreven. Hij koos daarvoor de titel "Nabeschouwing over een debat". Zijn grondstelling is "voor goede moraal is de christelijke levensovertuiging onmisbaar" (Douma, 1996:76).

In zijn afscheidscollege is Douma ingegaan op de vraag of wij als christenen aan de discussie met algemene dan wel met christelijke argumenten zullen deelnemen (Douma, 1997). In een recent artikel in zijn bekende rubriek "Moreel beraad" in het Nederlands Dagblad is Douma op zijn afscheidscollege teruggekomen. Hij heeft in een nadere toelichting misverstanden die naar aanleiding van zijn afscheidscollege waren gerezen, rechtgezet en zijn positie duidelijk gemarkeerd (Douma, 1998). Aan het eind van deze bijdrage kom ik hierop terug.

Volledigheidshalve wijs ik nog op de Apeldoornse studie van Velema, Hoe christelijk is de christelijke ethiek? (Velema, 1983) en het artikel van Douma in de bundel voor Velema, "Het proprium in de christelijke moraal en ethiek" (Douma, 1991).

\section{De positie van Rendtorff}

\subsection{Uitgangspunt van zijn ethiek}

Ik begin met de positie van Rendtorff, op wie Pannenberg commentaar heeft geleverd. Rendtorff kiest zijn uitgangspunt in een algemene antropologie. Hij komt tot dit uitgangspunt vanuit de gedachte dat ethiek de theorie is van de manier waarop mensen leven. Men kan ook zeggen van de levenswijze van de mens (Lebensführung). "Ethik ist die Theorie der menschlichen Lebensführung" (Rendtorff, 1990:9), dat wil zeggen: de mens leidt een leven en is daarvan het verantwoordelijk subject. Deze verantwoordelijkheid geldt zowel jegens het subject zelf als jegens anderen, en niet in de laatste plaats jegens God. Ethiek begint daarmee dat de mens zichzelf als een opdracht verstaat, zo luidt de eerste zin van het Voorwoord. Deze stelling is een citaat van Wolfgang Trillhaas. "Alle Ethik beginnt damit, daß sich der Mensch selbst als eine Aufgabe versteht' (Wolfgang Trillhaas). Das Studium der Ethik baut sich aus einem Studium der Grundelemente auf, in denen sich die Aufgabe stellt" (Rendtorff, 1990:7). Ethiek is dus de bezinning op het mens-zijn van de mens, scherper nog op de opdracht en de verantwoordelijkheid die met dat mens-zijn is gegeven. In vertaling geef $\mathbf{i k}$ een citaat: De mens is verantwoordelijk als subject voor zijn manier van leven. Dat is het thema en het voorwerp van onderzoek van de ethiek.

Der Mensch ist verantwortlich für sein Leben, als einzelner wie in der Gemeinschaft mit anderen Menschen, im Kleinen persönlicher Lebensverhalltnisse wie im Großen gesellschaftlicher Strukturen, im praktischen 
Handeln wie im planenden Gestalten. Der Mensch ist verantwortlich als

Subjekt der Lebensführung. Das ist Thema und Gegenstand der Ethik (Rendtorff, 1990:9).

De notie verantwoordelijkheid impliceert de gedachte dat de mens als handelend subject van vooronderstellingen leeft, die hij niet zelf heeft geschapen. Deze vooronderstellingen zijn hem gegeven. Hij staat onder de verplichting daarvan.

Het uitgangspunt ligt in de werkelijkheid van het mens-zijn in deze wereld, en in de daarmee gegeven verantwoordelijkheden en verplichtingen. Ook de relatie tot God hoort bij deze werkelijkheid. De theologische these dat de mens zijn bestemming vindt in de gemeenschap met God, biedt een zinvolle fundering aan het uitgangspunt dat de mens persoon is.

Uitgaande van de werkelijkheid, waarin de mens als persoon verantwoordelijkheid draagt, heeft de ethiek van Rendtorff een antropologisch uitgangspunt. De mens is krachtens zijn geschapen zijn een religieus wezen. Rendtorffs antropologie draagt een impliciet religieus karakter. Zegt Rendtorff hiermee, dat zijn antropologie ook theologisch gefundeerd is? Het luistert hier nauw. Rendtorff heeft in zijn ethiek wel plaats voor de theologie. Deze is echter evenals zijn antropologie vóór-dogmatisch.

Op deze manier meent Rendtorff zich vrij te kunnen houden van een autoritairdogmatische inbreng in zowel de antropologie als in de ethiek. Hij kan vrijuit met niet-christenen discussiëren over ethiek, over verantwoordelijkheden en over verplichtingen zonder bij voorbaat door enige dogma of enige inbreng van de dogmatiek gebonden te zijn.

\subsection{Ethische theologie}

Voorzover hij in zijn ethiek theologie toelaat of verwerkt, spreekt hij van een ethische theologie. Deze is precies het tegendeel van bijvoorbeeld Barths dogmatische theologie en ethiek. Zoals bekend, begint Barth bij de theologie, met name de dogmatiek. Hij plaatst de ethiek binnen de dogmatiek (zie hiervoor Velema, 1990:20 e.v.). Bij Rendtorff is het precies omgekeerd. Hij ziet de ethiek als een zelfstandige wetenschap. De theologie is bijkomend. Ze is uiteindelijk niet afwezig noch overbodig. Ze is echter niet nodig als basis en evenmin als uitgangspunt. Theologie volgt dus op de ethiek.

Rendtorff wil een ethiek die vrij is van dogmatiek. Theologen kunnen tot dezelfde resultaten op het gebied van de ethiek komen, terwijl ze dogmatisch van elkaar verschillen

Juist omdat de ethiek vrij is van en vrij staat tegenover de dogmatiek, kan Rendtorff een open en naar zijn mening, onbevooroordeelde discussie voeren met 
iedere ethicus. Dat God (en daarmee de theologie) in zijn ethiek een plaats inneemt, is te danken aan zijn antropologie. Beter nog is het te zeggen: het is gegeven met de antropologie die het uitgangspunt is van zijn ethiek. Men behoeft er echter geen speciaal dogma op na te houden om de ethiek een theologische invulling te geven. De ethiek die voortvloeit uit de antropologie, kent haar eigen theologie. In de voorgaande zinnen heb ik reeds beknopt enkele lijnen samengevat van wat Rendtorff schrijft onder het thema "Ethik im Kontext der Theologie. Zur Aufgabe einer ethischen Theologie" (Rendtorff, 1990:37-46).

Men lette op wat Rendtorff beweegt. Hij zoekt geen a-theologische of atheistische ethiek. God is met het mens-zijn gegeven. Hij zoekt wel een ethiek, die niet door de dogmatiek aan banden is gelegd of monddood wordt gemaakt. De ethicus moet sua sponte in een ethische discussie God ter sprake kunnen brengen. De Kruijf noemt dit een apostolair motief (De Kruijf, 1997:133 e.v.). Van een apostolair motief te spreken is een welwillende interpretatie van Rendtorffs positie. Zelf zou ik eerder denken aan het verlangen om ethiek op een algemeen menselijke basis te bedrijven. $\mathrm{Er}$ is ook bij Rendtorff wel een bereidheid, zelfs een zeker verlangen om God en de theologie in de ethiek te betrekken. Dat gebeurt als de implicatie van redelijk nadenken over menselijke verantwoordelijkheid. Wie zich de verantwoordelijkheid, de opdracht en bestemming van de mens indenkt, kan om God niet heen. God heeft niet het eerste woord. Hij is gem̈pliceerd in het mens-zijn en komt bij nadenken en nader argumenteren ter sprake. Men is geneigd om, naar analogie van de behandeling van de godsbewijzen in vroeger eeuwen, te zeggen dat ethiek niet intrinsiek atheistisch kan zijn. Bij de ethische bezinning op het menselijk handelen, treedt God uit de anonimiteit waarin $\mathrm{Hij}$ tot dan gehuld was. Men bedenke dat ter typering van Rendtorffs antropologie, allereerst het woord religieus gebruikt moet worden. Daarna komt theologie in het gezichtsveld.

Ethiek bedrijven is per definitie aan theologie doen; althans als de ethicus het verstandig aanpakt en de goede lijn van redeneren en argumenteren weet te volgen. Rendtorff vat theologie op als christelijke theologie. In dat kader kan hij ook van christelijke ethiek spreken. De ethiek, die vanuit de antropologie wordt opgebouwd, krijgt dus een theologisch, en daarmee christelijk karakter. Dat gebeurt omdat de openbaring christelijke bouwstoffen levert. ${ }^{2}$ lk zou het zo willen typeren en samenvatten: ethiek is anonieme christelijke ethiek, terwijl ontvouwing van de ethiek het christelijk karakter van zijn anonimiteit ontdoet en aan het licht brengt. Dat er in deze ethiek geen sprake is van de prioriteit van de openbaring boven de werkelijkheid, is duidelijk.

2 Deze methode van redeneren doet mij denken aan de manier waarop Hans Küng komt tot het "Ja zum christlichen Gott" (Küng, 1978:641-767). 


\section{De reactie van Pannenberg}

\subsection{Kritiek op Rendtorff}

Pannenberg deelt bepaalde fundamentele inzichten met Rendtorff. De Kruijf zegt zelfs dat Pannenberg het voor het apostolaire motief van Rendtorff opneemt. Omdat we bij dat apostolaire motief een voorzichtig vraagteken hebben gezet, doen we dat ook bij de overeenkomst in apostolair motief.

Het bezwaar van Pannenberg is dat Rendtorff wel degelijk dogmatisch bezig is, terwijl deze dat juist ontkent. Pannenberg is het eens met Rendtorff dat elke ethiek betrekking moet hebben op de fundamentele situatie van de mens. Pannenberg spreekt in dit verband van levenssituatie. Hij stelt dan dat de vraag of de ethiek een religieuze fundering nodig heeft of niet, alleen besproken en beslist kan worden op basis van de antropologie. Deze beslissing kan terecht aanspraak maken op algemene geldigheid. "Auch die Frage, ob die Ethik einer religiösen Begründung bedarf oder nicht, kann mit Anspruch auf Allgemeingültigkeit nur auf der Basis der Anthropologie erörtert werden" (Pannenberg, 1996:81).

Pannenberg heeft in zijn in 1983 gepubliceerde boek Anthropologie in theologischer Perspective, de stelling verdedigd dat de thematiek van de religie onafscheidelijk bij het mens-zijn behoort. Religie is dus een thema dat met de antropologie is gegeven.

De mens is, zoals in de antropologie uit 1983 betoogd werd, een zichzelf transcenderend wezen. Hij is open naar de toekomst. Die openheid wijst op een behoefte, een onvervuld verlangen, dat zich uit in onrust. Rust vindt de mens alleen als hij God vindt als de Schepper van het leven. Rust komt er pas als we van Hem de bevrediging van onze dagelijkse behoeften afsmeken en verwachten. ${ }^{3}$

Vanuit de zo verstane relatie met God verandert het zelfverstaan van de mens. Zo leert de mens zijn leven zien als een gegeven leven. Deze formulering is fundamenteel in de ethiek van Rendtorff. Deze beroept zich hiervoor op Bonhoeffer. Hij spreekt in dit verband van de appèl-structuur van het gegeven leven (Rendtorff, 1990:62). ${ }^{4}$

Op dit punt nu constateert Pannenberg een tekort in de redenering van Rendtorff. Fundering in de schepping impliceert toch de gedachte dat God er is. Geen schepping zonder Schepper. Rendtorff wil echter niet weten van een explicite

3 Dezelfde gedachte vindt men ook reeds in zijn beknopte antropologic, welke verschoen onder de titel Was ist der Mensch (Pannenberg, 1968).

4 Pannenberg bespreekt deze passage van Rendtorff, op S 82ff van zijn bock uit 1996 
fundering van de ethiek in een leer over God. Op deze ontkenning richt zich de kritiek van Pannenberg.

Ethiek kan immers niet beginnen op het terrein van de godsleer. Ze is een zaak van de antropologie. Pannenberg erkent dat de gedachte van een theologische antropologie niet de bedoeling heeft de godsgedachte geheel af te schermen of uit te schakelen.

\subsection{Vanuit de Schepper vanuit de eschatologie}

De stelling van Pannenberg is dat in een theologische antropologie een godsleer is voorondersteld, op zijn minst in grondtrekken. Loopt dit dan niet uit op het model van een ethiek die gesubordineerd is aan de dogmatiek? Als Rendtorff of wie dan ook enkel van een algemene antropologie als grondslag voor de ethiek wil uitgaan, dan zou de gedachte aan God inderdaad geheel afwezig kunnen zijn.

$\mathrm{Nu}$ Rendtorff echter de theologie niet buiten de ethiek wil houden, kan hij volgens Pannenberg niet volstaan met de stelling dat de dogmatiek niets met de ethiek te maken heeft. Rendtorff gaat uit van het ontvangen hebben van het leven. Daarin ligt opgesloten de gedachte van "die Aktivităt des tätigen Lebens". En dan trekt Pannenberg de consequentie voor Rendtorff

$\mathrm{Da} \beta$ sich daraus die Forderung ergibt, 'ein Leben für andere zu fuihren', werden Christen sicherlich bejahen, aber das setzt bereits die christliche Glaubensperspektive und insbesondere die im vorigen Abschnitt erörterte Begründung des christlichen Liebesgedankens nach denn Vorbild der Liebe Gottes als Schöpfer und Vollender der Welt voraus (Pannenberg, 1996:83).

Ook vanuit de eschatologie maakt Pannenberg duidelijk dat de dogmatiek wel degelijk een rol speelt in Rendtorffs ethiek. In het slot van Rendtorffs ethiek lezen we dat het komen van het Rijk van God het theologisch doel is van de christelijke ethiek (Rendtorff, 1990:176 e.v.). Deze stelling raakt de verhouding van eschatologie en ethiek. In dit verband spreekt Rendtorff over een theoretische rechtvaardiging van de ethiek achteraf (Pannenberg, 1996:86).

Pannenberg stelt de vraag of deze opmerking niet terugwerkende kracht moet hebben in heel Rendtorffs ethiek. Met andere woorden: het Rijk van God heeft niet alleen wat met de eschatologie te maken, maar evenzeer iets met wat daaraan in de ethiek vooraf gaat, dus ook - zoals hierboven reeds werd gesteld - met de schepping, die in de notie van het gegeven leven aan de orde komt (Pannenberg, 1996:86).

Onze conclusie is dat Pannenberg in nog breder verband tracht duidelijk te maken dat de godsleer van het begin af aan een rol speelt in Rendtorffs concept van 
ethiek. In het volgende citaat geeft Pannenberg de positie van Rendtorff kernachtig weer.

Die anthropologische Basis der ethischen Argumentation muß zunächst für sich in den Blick kommen, ohne schon von den dogmatischen Voraussetzungen des Gottesgedanken her in einer ganz bestimmten Weise gedeutet zu sein. Das ist der Kern des Anliegens von Trutz Rendtorff, die Ethik nicht von der Gotteslehre her zu begründen (Pannenberg, 1996:86).

\subsection{Rendtorff heeft toch een dogmatische basis in zijn ethiek}

Tegen deze aanpak richt zich de kritiek van Pannenberg. Hij meent dat Rendtorff wel degelijk een theologische, ja zelfs een dogmatische basis in diens ethiek heeft aangebracht, namelijk door over een godsleer te spreken, zij het dat die godsleer niet is uitgewerkt.

Onze conclusie was reeds, dat een godsleer impliciet opgesloten ligt in Rendtorffs conceptie van de ethiek. Pannenberg doet eigenlijk niet anders dan exphciet maken wat wij de onuitgesproken implicatie van een (dogmatische) godsleer noemden. Pannenberg zegt in andere woorden hetzelfde als wat ik hierboven heb gesteld, namelijk dat de anonimiteit van de godsleer bij Rendtorff in de nadere ontvouwing van zijn ethiek wordt afgelegd.

\subsection{Pannenberg een voor-theologische antropologie}

Wat is nu de grondstelling van Pannenberg? Hij spreekt over een voor-theologische, wil men een voor-dogmatische antropologie. Op de basis van een voortheologische antropologie is de betekenis van de godsgedachte voor de ethiek te funderen. We wijzen terug op de mens als een zichzelf transcenderend wezen. De mens staat open naar de toekomst. Welnu, op deze basis, namelijk die van de antropologie, is er in de ethiek over God te spreken.

De mens verlangt naar het waarachtig goede. Dat is een antropologisch grondgegeven. Wat is de vervulling van het diepste verlangen van de mens naar het goede? Dat is de gemeenschap met God; en niet, zoals Kant stelt, een goede wil. Een theologische fundering van de ethiek rust op de voor-theologische antropologie. Gods heerschappij is de toekomst van de mens. Dit eschatologische perspectief van Gods heerschappij raakt ook de scheppingswerkelijkheid van de mens. De schepping vindt haar voleinding in de gemeenschap met God, oftewel in het deelnemen aan de beweging van Gods liefde (Pannenberg, 1996:104f.). 5 Brinkman (1979:4l-43). Brinkman spreekt over antropologisering. Men zie ook hierover Vroom (1978:181-185). 


\subsection{Rendtorff en Pannenberg gaan beiden van religie uit}

We maken de balans op. Ook Pannenberg gaat in zijn ethiek uit van een voortheologisch gegeven, namelijk van de antropologie. Ook bij Pannenberg is de religie in de antropologie ingebouwd.

Dit betekent dat Pannenberg niet anders dan Rendtorff ook van religie uitgaat. De godsgedachte is de vervulling; we kunnen ook zeggen de theologische explicitering van het wezen van de mens.

Wij vermogen niet in te zien dat de structuur van beider ethiek wezenlijk verschilt. Pannenberg verwijt Rendtorff dat deze, zonder het te beseffen en te erkennen, dogmatisch te werk gaat. Onze conclusie ten aanzien van Pannenberg is geen andere. We maken alleen deze opmerking: Pannenberg ziet de mens als religieus wezen. Op basis daarvan spreekt Pannenberg over God. Hij begint er niet mee, maar kan er niet aan ontkomen. God hoort er nu eenmaal bij. Zo is de godsgedachte gegeven met Pannenbergs antropologie. Structureel is er geen verschil tussen Pannenberg en Rendtorff. Dat concludeert De Kruijf terecht (De Kruijf, 1997:134).

\section{Vanuit het christelijk geloof?}

\section{1 Rendtorff en Pannenberg gaan beiden niet uit van het christelijk geloof}

We wenden ons nu tot de vraag of de besproken auteurs uitgaan van een algemeen uitgangspunt, dat door iedere ethicus kan worden ingenomen, dan wel of zij, respectievelijk een van hen beiden, uitgaat van het geloof als uitgangspunt. Deze paragraaf bevat in feite een explicitering van de grondstellingen van Pannenberg en Rendtorff, zoals zij in de vorige paragraaf reeds aan de orde werden gesteld.

Rendtorff heeft duidelijk gesteld dat hij zijn ethiek, ja de ethiek in het algemeen niet baseert op het christelijk geloof. Hij stelt met de dogmatiek eigenlijk alle bijzondere punten van het christelijk geloof terzijde. Hij wil er niet aan of door gebonden zijn. Ze zijn voor hem basis noch uitgangspunt voor de ethiek. Die is algemeen.

We zagen dat hij het christelijk geloof niet geheel heeft afgeschreven. Vandaar de term ethische theologie. Het komt echter pas in een later stadium binnen het gezichtsveld. Pannenberg verwijt hem dat er toch meer theologie in zijn ethiek ingebouwd zit, dan Rendtorff waar wil hebben. Hij nodigt hem uit dat te erkennen en dat ook duidelijk te verdisconteren. 
Pannenberg zelf gaat uit van de antropologie, een voor-theologische en voordogmatische antropologie; dus evenmin van het expliciet beleden christelijk geloof of dogma. Pannenberg ziet de mens als religieus wezen. Vandaar dat religie en geloof van het begin af aan meespelen in zijn visie op de mens en in zijn ontwikkeling van de leer van de mens.

Voor Pannenberg is het niet meer dan een stap om deze religieuze gestructureerdheid van de mens te verbinden met het christelijk geloof. In zekere zin was dat ook bij Rendtorff het geval. Alleen sprak deze zich over religie en de religieuze aanleg van de mens niet uit. Pas later bleek die goed te passen bij zijn mensbeeld.

\subsection{De mens als religieus wezen}

Onze conclusie was toen reeds dat wat Pannenberg expliciet meetelt, bij Rendtorff impliciet aanwezig is. Op dit punt zien wij geen wezenlijk verschil. Beide auteurs gaan ervan uit, dat er een vrij soepele overgang is van het religieuszijn van de mens, naar de aansluiting van het christelijk geloof bij die aanleg. In dit verband zou men het begrippenpaar continuïteit en discontinuilteit kunnen gebruiken.

\subsection{Toch een christelijke inbreng in de ethiek}

Er is discontinuiteit in zoverre het algemeen menselijke religieus-zijn niet met het christelijke samenvalt. Tussen beide is er verschil. Vandaar discontinuiteit. Het verschil bestaat niet in een breuk. Er vindt echter een welhaast vanzelfsprekende aansluiting plaats van het christelijk geloof bij het algemeen menselijke religieuszijn. Vandaar continuitteit. De continuïteit domineert. Beide auteurs ontkennen de expliciete fundering van de ethiek in het christelijk geloof. Er is wel een directe samenhang van ethiek en religie. Met religie is hier niet bedoeld het christelijk geloof, dat teruggaat op de openbaring van Christus, zoals we die in de Heilige Schrift hebben ontvangen. Deze openbaring sluit echter wel aan bij het religieuszijn van de mens.

Terzake van de relatie religie, christelijk geloof en ethiek verraadt zich de apologetische instelling van met name Pannenberg. Hij is voortdurend weer erop uit het christelijk geloof voor de hedendaagse mens als een bij hem passende en voor hem acceptabele vorm van godsdienst voor te stellen. De mens is van nature godsdienstig. Daarom telt de religie mee voor het funderen van de ethiek; religie als algemeen menselijk verschijnsel. De mens kan uit zichzelf tot God en de kennis van God komen. Men bedenke hoe welgezindheid als filosofische deugd en agapè als christelijke deugd volgens Pannenberg bij elkaar passen. Ze gaan zomaar in elkaar over (Pannenberg, 1996:77-80). Zelfs de breuk door de zonde is geen onoverkomelijke kloof. Het Koninkrijk van God is immers de "natuurlijke" 
bestemming van de mens. ${ }^{6}$ De openbaring heeft derhalve geen funderende functie voor de ethiek. Men kan hoogstens spreken van een aanvullende functie. Deze aanvulling verduidelijkt en preciseert wat in feite gegeven is met ons mens-zijn. Pannenberg (1996:104-107) zelf spreekt in dit verband over een christelijk perspectief. ${ }^{7}$ Het gaat te ver hier de inhoud te releveren van paragraaf 3 "Anthropologische Voraussetzungen christlicher Ethik". Deze paragraaf is een onderdeel van hoofdstuk 5, waarin Pannenberg (1.996:95-107) "Christliche Ethik und die menschliche Allgemeinheit der Ethischen" behandelt. In dit hoofdstuk gebruikt Pannenberg (1996:104) de uitdrukking "eine Besinnung auf die spezifisch christlichen Modificationen". Het gaat dus om een specifieke christelijke modificatie van een antropologische basis.

\section{Een algemeen menselijk fundament?}

\subsection{Douma's positie}

We staan nu opnieuw voor de vraag of we ethiek kunnen bouwen op een algemeen menselijk fundament, dan wel of we voor een ethiek, zoals God die van ons vraagt, het fundament van de openbaring nodig hebben.

In een vorige publicatie heb ik het dilemma als volgt verwoord: verlichting of openbaring (Velema, 1983:14 e.v.). Toen heb ik onvoorwaardelijk gekozen voor de openbaring als het fundament van de christelijke ethiek. Onder openbaring versta ik zowel de algemene als de bijzondere openbaring. Voor het onderscheid en de samenhang van beide zie men Van Genderen et al. (1992:53-66). We zijn nu vijftien jaar verder. Er is in gereformeerde kringen in Nederland nagedacht over de houdbaarheid van het dilemma, verlichting of openbaring. Met name Douma heeft er in de laatste jaren op gewezen dat bepaalde standpunten met algemene argumenten kunnen worden verdedigd, terwijl andere standpunten alleen met specifiek christelijke argumenten kunnen worden verdedigd.

Douma heeft in zijn afscheidscollege gewezen op het eigene van de christelijke moraal. Hij heeft gesteld dat "het in Nederland op moraal gebiede armoede troef is zonder het christelijke geloof" (Douma, 1997; 1998). Hij wenst bij geen enkel onderwerp het christelijk geloof buiten de deur te houden (Douma, 1998).

Hij pleit in zijn afscheidscollege voor een analyse van de heersende algemene moraal. De christelijke moraal moet aan de Nederlandse samenleving een dienst willen bewijzen in haar waardering van en kritiek op deze moraal (Douma, 1997).

6 Pannenberg hoeft hierover uitvoerig geschreven in zijn opstel "Das Problem einer Begründung der Ethik und die Gottesherrschaft" (Pannenberg, 1971:63-78).

7 Men zie ook de titel van zjn uitvoerige studie Anthropologie in theologischer Perspektive (1983). 
Een dergelijke instelling, zo vervolgt Douma zijn conclusie, vergt dat we ook kunnen communiceren met algemene argumenten. We moeten ons niet te snel terugtrekken op de laatste linies, waar we alleen met christelijke argumenten uitkomen, en zoveel mogelijk proberen duidelijk te maken dat het voor de moraal goed en nuttig is de geboden van God te onderhouden.

Op de plaats, de functie en reikwijdte van algemene argumenten, te gebruiken door een christelijke ethiek, wil ik straks iets dieper ingaan.

\subsection{Argumenten ten gunste van een christelijke ethiek}

Laat ik de voornaamste argumenten ten gunste van de noodzaak van een aparte christelijke ethiek nog eenmaal samenvattend mogen herhalen. Ik ga dan terug naar mijn rectorale rede die vijftien jaar geleden is verschenen (Velema, 1983:2130). Daar wordt met nadruk gewezen op de eenheid van heil en heiliging, wil men van geloof en leven. Vanuit die eenheid is het ondenkbaar dat de mens voor de kennis van het heil op de openbaring van God zou zijn aangewezen, terwijl hij voor de kennis van regels voor een goed en verantwoord leven op zichzelf zou zijn aangewezen. Er ontstaat een diepe breuk in de boodschap van de Bijbel, wanneer men voor de kennis van God en het geloof in Hem wel van de Bijbel afhankelijk is, maar voor het zedelijke leven in deze wereld op eigen inzichten zou zijn aangewezen. Men bedenke dat de Decaloog bestaat uit twee tafels die men niet van elkaar mag losmaken.

Bovendien wordt er door mij in deze studie op gewezen dat het theocentrisch karakter van de heiliging inhoudelijke consequenties heeft. De liefdesboodschap van de Bijbel gaat terug op de liefde van God, zoals Hij deze heeft geopenbaard in de zending van Zijn Zoon Jezus Christus. Dit gegeven van christelijke liefde is volstrekt uniek in de ethiek. Hiermee is niet gezegd dat ethiek die niet van openbaring uitgaat, geen enkele betekenis heeft. Zij heeft wel degelijk betekenis. Denk aan de grote plaats die Aristoteles in de geschiedenis van de ethiek inneemt. Deze betekenis vermindert echter het spreken over het goed recht van een christelijke ethiek op geen enkele wijze.

Daarnaast is er in de ethiek toch altijd weer de opdracht om een antwoord te geven op de manier waarop wij met de gebrokenheid van het leven en de onvolkomenheid van het bestaan omgaan. De christelijke ethiek geeft vanuit het evangelie daar wel een volstrekt eigen en uniek antwoord op.

Tenslotte zij erop gewezen dat in de Bijbel niet alleen de geboden van God een plaats hebben. Ze zijn normatieve aanwijzingen voor mensen die in gehoorzaamheid aan God willen leven. Er zijn meer gegevens die een normatieve betekenis hebben. In zekere zin kan men zeggen dat de geboden juist aansluiten en precies passen bij deze normatieve gegevens. De decaloog in zijn totaliteit is een vorm 
van wetgeving die zich richt tot de mens die naar het beeld van God geschapen is. Men zal de bijbelse, normatieve notie van geschapen naar Gods beeld in de ethiek bij tal van onderwerpen moeten verdisconteren.

De conclusie moet zijn dat men in de bijbelse boodschap niet een zodanige scheiding teweeg mag brengen, dat men voor het heil op Gods openbaring is aangewezen en voor het ethos naar de mens zelf kan wijzen. In de bijbelse openbaring zijn heil en ethos één.

\section{Het gaat om een totaalvisie}

\subsection{Privé- en publieke moraal}

Het voorgaande leidt tot de stelling, dat het bij het ethos om een totaalvisie en een totaalconcept gaat. Ethiek is levens- en wereldbeschouwelijk bepaald. Ethiek is de wetenschappelijke bezinning op de moraal, ofwel het ethos. Dat wil zeggen op het handelen van de mens onder het gezichtspunt van goed en kwaad. Christelijke ethiek is de bezinning op het handelen van de mens die geschapen is naar Gods beeld, in zaken van goed en kwaad, in gehoorzaamheid aan het evangelie van Jezus Christus.

De onderscheiding van brede en smalle moraal wordt tegenwoordig veel gehanteerd (zie hiervoor Musschenga, 1989:160-162). Zij wordt onderscheiden in privé-moraal en publieke moraal. Zij leidt tot een scheiding van levensterreinen. Ieder privépersoon neemt deel aan het openbare leven. Hij beweegt zich op het publieke domein (terrein). Het is op zijn minst merkwaardig dat een mens met tweeërlei verschillende normen zou werken; dat hij naar twee verschillende soorten normen zou leven.

Zoals de eeuwen door de vraag is gesteld bij de verdediging van een tweeterreinen-leer, moet ook hier de vraag gesteld worden: gelden de normen van de smalle moraal ook op het terrein van de brede moraal? Wordt de brede moraal dus mede (in)gevuld door wat de smalle moraal voorschrijft? Of is er een absolute scheiding van de beide terreinen, als gevolg waarvan elk terrein zijn eigen normen heeft? Dat zou betekenen dat een mens te doen heeft met twee normen en ook waardensystemen. De nu besproken onderscheiding leidt inderdaad tot een scheiding tussen privé- en publieke moraal.

Is zulk een scheiding psychologisch denkbaar en doorvoerbaar? Zeker, men kan zich indenken dat het publieke terrein verplichtingen meebrengt, die zich op het privé-terrein niet voordoen. Evenzeer is het denkbaar dat het privé-domein meer omvat qua terrein en dus ook qua verplichtingen dan het publieke domein en dat men als gevolg hiervan zou kunnen zeggen: er is verschil in verplichtingen. Is er daarom ook verschil in hiermee samenhangende normen? 


\subsection{De eenheid van de normen}

Men kan geen splitsing aanbrengen, alsof de beide moralen totaal verschillend en zelfs tegenstrijdig zouden zijn. Trouw, eerlijkheid, geen schade toebrengen, weldoen en leven in stand houden, leven bevorderen en schade vergoeden, niet liegen, niet stelen zijn normen die als ze op het ene terrein van kracht zijn, ook op het andere terrein gelden.

Het leven is een eenheid. Zo ook ons normen- en waardenstelsel. Het eigene van ons normenstelsel is, dat het geen beperkte geldigheid heeft, maar van kracht is over de volle breedte van ons leven.

Behalve de breedte-dimensie, is daar ook de diepte- (als herkomst) en de hoogte(als toekomst) dimensie.

Bijbels gezien, mag men de geboden niet isoleren en evenmin fragmentariseren. Hiermee bedoel ik dat men ze niet los mag maken uit het geheel van onze wereldbeschouwing noch ze op zichzelf stellen.

Dat wordt tegenwoordig vaak gedaan. Voor dit op zichzelf plaatsen gebruiken we termen als isoleren, fragmentariseren, functionaliseren en zelfs individualiseren. Deze vier werkwoorden zijn niet van volstrekt gelijke betekenis. Ze hebben wel eenzelfde intentie. Die is deze: het geval, de situatie op zichzelf stellen en daarvoor een norm zoeken, die dienstbaar is aan een beslissing.

Wie dat doet, ontbindt het normensysteem in factoren, die op zichzelf voldoende zijn om een beslissing te forceren. Men is echter de samenhang kwijt. Dat verlies van samenhang geldt zowel de feiten als de normen.

Het voorrecht van Gods openbaring bestaat hierin dat zij ons een totaalvisie op het leven biedt. In die visie is plaats voor verscheidenheid van situaties, gevallen, relaties en verplichtingen. $\mathrm{Er}$ is ook plaats voor verscheidenheid van morele voorschriften en normen.

Er is echter geen plaats voor een doorbreking van de samenhang, voor het op zichzelf stellen van situaties, relaties en gevallen, noch voor het isoleren van de normen. In de fenomenale verscheidenheid is er een overkoepelende eenheid. Hiermee is waarachtigheid, betrouwbaarheid, integriteit en authenticiteit gegeven. Ik stel dit op grond van de ons door God gegeven normen, die we kennen door de algemene en de bijzondere openbaring. Pannenberg kent ook zulk een eenheid. Haar fundament is echter een ander dan dat van de openbaring (zie paragraaf 3 ).

\section{De samenhang van abortus en euthanasie}

Douma heeft zijn stelling dat we als christenen ook met algemene argumenten kunnen argumenteren toegelicht met een verwijzing naar het verschil tussen 
abortus en euthanasie. Terzake van abortus zou men een algemeen argument kunnen aanvoeren, waarvan de redelijkheid ook door niet-christenen moet en kan worden ingezien. Het gaat immers om een ander leven dan dat van de vrouw.

Tegen euthanasie is een dergelijk algemeen argument niet aan te voeren. Euthanasie kan men als christen alleen afwijzen met een beroep op het feit dat God Schepper en Gever van het leven is (Douma, 1997).

De onderscheiding tussen deze twee, waarbij voor het afwijzen van abortus een algemene en voor het afwijzen van euthanasie een speciaal christelijke argumentatie van kracht zou zijn, lijkt me niet juist. Men kan voor euthanasie ook wijzen op het klimaat dat in een samenleving ontstaat, en op het toepassen van euthanasie op wilsonbekwamen, als gevolg van dit klimaat.

Beide onderwerpen maken deel uit van het publieke terrein. Ze hebben wezenlijk met elkaar te maken. Wie tegen abortus is, zal dezelfde argumenten gebruiken in zijn afwijzing van euthanasie. Het gaat bij beide om de vraag of de mens over leven en dood mag beschikken. De liberalisering van abortus heeft binnen betrekkelijke korte tijd geleid tot liberalisering van euthanasie. In de jaren voor 1981 is onzerzijds op die te verwachten snelle ontwikkeling gewezen. Er is een directe innerlijke samenhang, die haar eigen dynamiek meebrengt, in dit geval de dynamiek van het kwaad.

Waar ligt de oorsprong van wat wij noemen de liberalisering van abortus en euthanasie? In het feit dat men als mens zelf over het beëindigen van het leven meent te mogen beslissen. Wie dat aan het begin, via het besluit tot abortus meent te mogen doen, kan zijn handen bij het eind van het leven niet thuishouden. Het recht op het vragen om of het plegen van euthanasie, ligt in het verlengde; men kan ook zeggen het is de innerlijke consequentie van het recht om abortus te plegen. Hier is een nauwe samenhang. Dat is deze: of men meent zelf over het leven te mogen beslissen, of dat men het als gave (en opdracht) van God meent te moeten eerbiedigen.

Men kan erop wijzen, dat bij abortus een ander zelfstandig leven in het geding is. Dat is een algemeen argument. Overigens, slechts tot op zekere hoogte, want niet iedere bioloog, antropoloog of zelfs theoloog is deze mening toegedaan. Maar zelfs al zou men het hierover eens zijn, dan komt nog niet een ieder tot dezelfde beslissing. Dat is geen wonder. Wie aan het einde over het leven meent te mogen beslissen, kan dat recht als hoogste norm ook laten gelden in gevallen van abortus. Waarom zou daar dat beschikkingsrecht over leven en dood niet mogen domineren in (uitzonderlijke) noodsituaties? Beide beslissingen worden door dezelfde overkoepelende norm bepaald. 
En omgekeerd, wie meent levenbeëindiging in uitzonderlijke uitzichtloze noodsituaties te mogen toepassen, die kan er niet aan ontkomen om dat ook voor hen te doen gelden die zelf niet meer kunnen beslissen. Er ontstaat dan een euthanasieklimaat, dat door de erkenning van het recht van een enkeling op euthanasie wordt geschapen en geïntensiveerd.

Men bedenke dat voorstanders van euthanasie alleen op verzoek, in de loop van luttele jaren gekomen zijn tot verdediging van euthanasie bij wilsonbekwamen. Kuitert is hiervan een welsprekend voorbeeld (Kuitert, 1981 en 1993:81-116).

Deze laatste passage laat zien dat de redenering van Douma in het onderscheid van het gebruiken van algemene argumenten bij afwijzing van abortus en in het moeten gebruiken van speciaal christelijke argumenten in het afwijzen van euthanasie, door de feiten wordt weersproken.

Uit deze redenering trek ik vooral de conclusie dat bepaalde argumenten die op zichzelf, incidenteel worden gehanteerd, niet geïsoleerd mogen worden gebruikt. Ze passen in een groter geheel. Dat geheel moet in de discussie gehonoreerd worden. Hetzelfde betogen De Vries (1997) en Kuiper (1997).

Christenen kunnen wel wijzen op bepaalde algemene gevolgen van een bepaalde beslissing. Douma heeft het goed recht om dat te doen, en voor dit recht als christen aandacht te vragen. Die algemene gevolgen staan echter niet op zichzelf.

Onzerzijds is met nadruk gesteld dat de wet van God heilig en goed is. Dat geldt voor ieder mens. Wie de wet overtreedt, tast de goedheid van de wet aan. Die aantasting leidt tot kwalijke gevolgen.

In de ene situatie zijn die kwalijke gevolgen evidenter en sneller herkenbaar als gevolgen van het schenden van de wet van God, dan in het andere geval. Men zal echter het geval, de situatie nooit los mogen maken van de wet als wet van God.

Een christen zal ten diepste altijd op de wet als Gods wet terugvallen. De wet op zichzelf en de goedheid van het gebod kunnen niet losgemaakt worden van God als de Wetgever. Wie dat wel doet, vervalt in formalisme, zelfs in een zeker wetticisme.

We zullen steeds de vraag moeten stellen en beantwoorden: vanwaar komt de norm en waartoe dient zij? Het normenvraagstuk is voor ons een religieus vraagstuk. Om misverstand te voorkomen, citeer ik het slot van Douma's toelichting op zijn afscheidscollege. "Alles wat we als 'algemeen' waarderen (en ieder doet dat, zelfs al zou hij beweren van niet), krijgt binnen dat christelijke kader zijn wettige en waardevolle plaats" (Douma, 1998). Deze conclusie onderstreep ik gaame. Het algemene kan niet op zichzelf staan, maar past binnen een groter, christelijk kader. 


\section{De goedheid van God en van Zijn wet}

\subsection{Consensus ten koste van het belijden}

Normen zijn er ten dienste van het welzijn van mensen, wier hoogste roeping het is God te dienen. Deze normen kunnen nooit van die bestemming van mensen worden losgemaakt. Daarom mogen ze ook niet anoniem gehanteerd worden.

Wie alleen op de consensus let (dus werkt met algemene argumenten), doet tekort aan het opkomen voor het publiek karakter van de door God gegeven normen. Dat publieke karakter vraagt ook om een publiek getuigenis omtrent herkomst en doelstelling.

Wie zich hiervan losmaakt, kan wel incidenteel tot overeenstemming komen, maar in de totaliteit van het leven rekent hij zich rijker dan hij is. Die vermeende rijkdom heeft als keerzij een armoede aan het publieke getuigenis omtrent het recht en de wetten van God.

Waaraan is het te danken dat christenen en niet-christenenen dezelfde argumenten kunnen gebruiken? Wij mensen zijn door God geschapen. God heeft zijn wetten voor alle mensen gegeven, niet alleen voor de gelovigen. Daarvan blijft ook na de zondeval iets herkenbaar. Ik zeg niet over de volle breedte. Ik zeg evenmin in alle tijden evenveel. De innerlijke verdorvenheid neemt toe (Op. 22:11). Met de toename van de verdorvenheid zal de consensus tussen christenen en nietchristenen verminderen. De hierboven besproken algemeenheid is dan ook aan verandering, aan vermindering onderhevig. We spreken in dit verband van een dynamisering van het kwaad.

\subsection{Algemene openbaring en Gods goedheid}

Voor zover die overeenstemming er is, is zij te danken aan de goedheid van de wet, die zich tot alle mensen richt (enerzijds) en aan de algemene goedheid van God, die de voortgang van het kwaad, vooral uitkomend in de miskenning van de goedheid van de wet, afremt (anderzijds). Berkouwer schrijft het kenbaar zijn van de algemene openbaring onder de mensen toe aan Gods algemene goedheid (Berkouwer, 1951:166-174). Op bepaalde momenten neemt God de remmende werking van zijn algemene goedheid terug. Dan vindt plaats wat we lezen in Romeinen 1, dat God mensen overgeeft in hun hartstocht aan onreinheid (1:24), aan schandelijke lusten (1:26), aan een verwerpelijk denken om te doen wat niet betaamt (1:28).

Dit overgeven van mensen aan hun zondige begeerten betekent niet dat de goedheid van de wet verdwijnt. Die blijft van kracht en kan als argument in ethische discussies worden ingebracht. Het betekent wel, dat mensen niet langer, of hoe langer hoe minder bereid zijn om de goedheid van de wet te erkennen. Dat leidt 
tot conflicten in plaats van tot consensus. Dit proces is in Nederland, onder leiding van een paars kabinet in volle gang.

Het is het tegendeel van wat Paulus kon schrijven in Filippenzen 4:8 en 9:

Voorts, broeders, al wat waar, al wat waardig, al wat rechtvaardig is, al wat rein, al wat beminnelijk, al wat welluidend is, al wat deugd heet en lof verdient, bedenkt dat; wat u geleerd en overgeleverd is, wat gij van mij gehoord en gezien hebt, brengt dat in toepassing en de God des vredes zal met u zijn.

Deze noties, normen en waarden waren in de toenmalige, hellenistische wereld gangbaar. In onze cultuur is er een enorme ontwaarding van normen en waarden aan de gang. Het kwaad schrijdt voort. God trekt remmen terug en laat de mens zijn gang gaan.

\section{Kan moraal zonder godsdienst?}

Ik zie nog eenmaal de vraag onder ogen of moraal zonder godsdienst kan. Soms wordt dat, ook van christelijke zijde, met enig gemak geponeerd. Ik zou dat bevestigende antwoord toch wat willen nuanceren. Inderdaad, de mens is een moreel wezen. Hij kan niet zonder moraal. Wel is de vraag wat de kwaliteit van een moraal zonder godsdienst is. Het atheisme zal die moraal kenmerken.

Ik heb gewezen op de noodzaak van een samenhang met het geheel. Zo is het hier ook. Moraliteit staat niet op zichzelf. Moreel-zijn is geen algemeen gebeuren. Het maakt deel uit van een groter geheel. Kan men een enkele positieve morele daad of houding grotelijks waarderen binnen een verdorven geheel? Bijvoorbeeld het schoonhouden van de straten of uit angst voor strenge straffen een hoogstaande belastingmoraal? Moeten we hier het geheel van de moraal niet in rekening brengen? Enkele onderdelen mogen positief zijn. Plus maal min is min. Dat wil zeggen: het incidenteel goede maakt het totale beeld niet goed.

\section{Terug naar het begin}

In een niet-christelijke moraal zijn evenals in een niet-christelijke ethiek, dankzij Gods algemene goedheid, sporen van de algemene openbaring. Deze sporen worden daar niet aan Gods openbaring toegeschreven. Zij dragen een accidenteel en fragmentarisch karakter (zie paragraaf 6.2).

Het belang van het hier verdedigde standpunt is gegeven met onze positie als christenen in de moderne cultuur. Ook het omgekeerde geldt: onze positie als christenen in de moderne cultuur vraagt om een totaliteitsvisie vanuit de heerschappij en de openbaring van God. 
Wij kunnen uit dat geheel wel elementen uitlichten en die in de discussie met anderen ter sprake brengen. Dat is niet zinloos noch nutteloos. We schieten als belijdende christenen tekort, als wij ons tot dit fragmentarische en incidentele gebruik beperken. Belijden is steeds weer een zaak van concretiseren en actualiseren in de situatie.

Daarom kunnen wij met een vorm van anonieme algemeenheid niet toe. Hiermee zijn we terug bij het begin van dit opstel.

Dat is de vraag of we ethiek kunnen funderen op een algemeen fundament van antropologie zonder dat we de openbaring van God daarbij ter sprake brengen dan wel of we het fundament zoeken in het Woord van God, op gevaar af dat we de relatie met niet-christenen onder zware druk zetten. Daarmee bemoeilijken we, zo beseffen we, de discussie. Aan het eind van dit opstel zien we een tweevoudige beweging plaatsvinden. Precies van tegenovergestelde richting naar het midden, naar het centrum. Pannenberg en eigenlijk ook Rendtorff gaan uit van ethiek als menselijk fenomeen, waarbij religie inbegrepen is. Deze religie sluit naatloos aan bij het menselijk bestaan. $\mathrm{Ze}$ is de ontvouwing van het mens-zijn. Daarom heeft de mens uit zichzelf toegang tot de religie. Deze heeft geen ander fundament dan het mens-zijn zelf. Religie en ethiek liggen in elkaars verlengde en zijn zonder tussenkomt van Boven voor elkaar open.

Onze positie is een precies tegenovergestelde. Wij kunnen niet bij de mens beginnen. Wij starten bij wat God over de mens zegt en van de mens vraagt. Gods Woord en Gods wet gelden voor alle mensen. Daarom kunnen we verwachten dat er algemene sporen van deze wetten gevonden, herkend en erkend worden. Daarover kan gediscussieerd worden. Die discussie is echter incidenteel, fragmentarisch en vaak functioneel. Er is derhalve, ook vanuit dit vertrekpunt, een ontmoeting in het centrum mogelijk. Die ontmoeting is van andere aard dan in de redenering van Pannenberg. Daar is het bijzondere als fundament afwezig. De discussie vindt plaats op algemene bodem. Het christelijke is bijkomend. In wezen brengt het niets nieuws. Het heeft slechts explicerende betekenis. Het verduidelijkt en vult aan.

Van het christelijk geloof uit gezien gaat het om de heerschappij van God, om de dominantie van Zijn Woord en wet. Wat daarvan bij anderen aanwezig is en in discussies herkend en erkend wordt, heeft de mens niet uit zichzelf. Hij heeft dat als restant, dus als overblijfsel dankzij Gods algemene openbaring. Deze rest kan alleen ten volle naar Gods bedoeling functioneren binnen het kader van de bijzondere openbaring. Dan komen de resten, in vernieuwing, herstel en restauratie pas tot hun volle recht. Dat was ook de conclusie van Douma's nadere toelichting (zie slot - paragraaf 7). 
Zo staan we met het thema "christelijke ethiek in een moderne cultuur" voor een enigszins dialectische positie. Anders en toch punten van herkenning - in tegenstelling tot algemeenheid met incidentele aanvulling van nog iets christelijks.

\section{Bibliografie}

BERKOUWER, G.C. 1951. Dogmatische studiën. De algemene openbaring. Kampen : Kok

BRINKMAN, ME. 1979. Het Gods- en mensbegrip in de theologie van Wolfhart Pannenberg. Een schets van de ontwikkeling van zijn theologie vanaf 1953 tot 1979. Kampen: Kok.

DE KRUIJF, G.G. 1994. Gebruiken en genieten. Een bruikbare onderscheiding in de christelijke ethiek. Leiden : Rijks Universiteit.

DE KRUIJF, G.G. 1997. Fundamenteel ethisch onderzoek vanaf 1980 in het perspectief van de protestantse theologie. Een overzicht. Nederlands Theologische Tijdschrift, 51:117-134.

DE VRIES, J.P 1997. Moraal met of zonder christelijk geloof. Nederlands Dagblad, februari, 14.

DE VRIES, J.P. 1997. De kracht van algemene argumenten. Trourw, juni, 4

DOUMA, J 1991. Het proprium in de christelijke moraal en ethiek. (In Van Genderen, J., Van 't Spijker, W. \& De Vuyst, J. Ten dienste van het Woord. Opstellen aangeboden aan prof. dr. W H. Velema. Kampen : Kok. p. 55-73.)

DOUMA, J. 1996. Nabeschouwing over een debat. (In Werkman, L. Niet onder stoelen of banken. In discussie met de ethicus Gerrit Manenschijn. Baam : Ten Have. p. 68-83.)

DOUMA, J. 1997. Met algemene of christelijke argumenten? Nederlands Dagblad. 13, mei 30.

DOUMA, J. 1998. Wat zijn algemene argumenten waard? Nederlands Dagblad. 4, januari, 3.

GABLER, K.U., MANENSCHIJN, G, MEULEMAN, G.E., MONTSMA J.A. \& REINDERS, J.S. 1989. Geloof dat te denken geeft. Opstellen aangeboden aan prof. dr. H.M. Kuitert. Baarn : Ten Have.

KUIPER, R. 1997. Algemene en christelijke argumenten in de politiek. Nederlands Dagblad 7 , juli, 2.

KUITERT, H.M 1981. Een gewenste dood. Euthanasie en zelfbeschikking als moreel en godsdienstig probleem Baam : Ten Have.

KUITERT, H.M. 1993. Mag er een eind komen aan het bittere einde? Levensbeëindiging in de context van stervensbegeleiding. Baarn : Ten Have.

KÜNG, H. 1978. Existiert Gott? Antwort auf die Gottesfrage der Neuzeit. München Zürich Piper Verlag.

MUSSCHENGA, A.W. 1989. De universele moraal als opdracht. (In Gabler, K.U., Manenschijn, G., Meuleman, G.E., Montsma J.A. \& Reinders, J.S. Geloof dat te denken geeft Opstellen aangeboden aan prof. dr. H.M. Kuitert. Baam : Ten Have. p. 159-178.)

PANNENBERG, W. 1968. Was ist der Mensch? Die Anthropologie der Gegenwart im Lichte der Theologie. Göttingen : Vandenhoeck \& Ruprecht. 3. Auflage.

PANNENBERG, W. 1971 Das problem einer Begründung der Ethik und die Gottesherrschaft. (In Theologie und Reich Gottes. Gütersloh : Gütersloher Verlagshaus Gerd Mohn p. 63-78.)

PANNENBERG, W. 1983. Anthropologie in theologischer Perspektive. Göttingen : Vandenhoeck \& Ruprecht.

PANNENBERG, W. 1996 Christeliche Ethik und die menschliche Allgemeinheit der Ethischen. (In Grundlagen der Ethik. Philosophisch-theologische Perspektiven Gottingen : Vandenhoeck \& Ruprecht p. 95-107.)

RENDTORFF, T, 1990. Ethik. Grundelemente, Methodologie und Konkretionen einer ethischen Theologie Band 1. Stuttgart Berlin Koln : Verlag Kohlhammer 2. Auflage. 
STEENHUIS, H P 1996. Het debat over de moraal Amsterdam : Trouw.

VAN GENDEREN, J., VAN 'T SPIJKER W. \& DE VUYST, J. 1991. Ten dienste van het Woord. Opstellen aangeboden aan prof. dr. W.H. Velema ter gelegenheid van zijn vijfentwintigjarig ambtsjubileum. Kampen : Kok.

VELEMA, W.H. 1983. Hoe Christelijk is de Christelijke ethiek? Over het eigene van de christelijke ethiek. Kampen : Kok.

VELEMA, W.H. 1990. Orientatie in de christelijke ethiek. 's-Gravenhage : Boekencentrum B.V.

VELEMA, W.H 1992. Beknopte gereformeerde dogmatiek. Kampen : Kok.

VROOM, H.M. 1978 De Schrift alleen? Een vergelijkend onderzoek naar de toetsing van theologische uitspraken volgens de openbaringstheologische visie van Torrance en de hermeneutisch-theologische opvattingen van Van Buren, Eberling, Moltmann en Pannenberg. Kampen : Kok.

WERKMAN, L. 1996. Niet onder stoelen of banken. In discussie met de ethicus Gerrit Manenschijn. Baarn : Ten Have 
